\title{
From Patna to Paris: Providing safe and humane abortion
}

\author{
Carmen Barroso \\ Martha Brady \\ Population Council \\ Batya Elul \\ Population Council \\ Shelley Clark \\ Sneh Vishwanath
}

See next page for additional authors

Follow this and additional works at: https://knowledgecommons.popcouncil.org/departments_sbsr-pgy

Part of the Family, Life Course, and Society Commons, Gender and Sexuality Commons, International Public Health Commons, Public Health Education and Promotion Commons, and the Women's Health Commons

How does access to this work benefit you? Let us know!

\section{Recommended Citation}

Barroso, Carmen, Martha Brady, Batya Elul, Shelley Clark, Sneh Vishwanath, and Sunanda Rabindranathan. 2001. "From Patna to Paris: Providing safe and humane abortion," Quality/Calidad/Qualité no. 11. New York: Population Council. 


\section{Authors}

Carmen Barroso, Martha Brady, Batya Elul, Shelley Clark, Sneh Vishwanath, and Sunanda Rabindranathan 
From Patna to Paris: Providing Safe and Humane Abortion
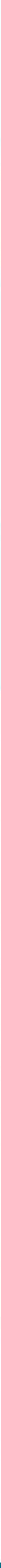

\section{té/Quality/Calidad/Qualité/(}




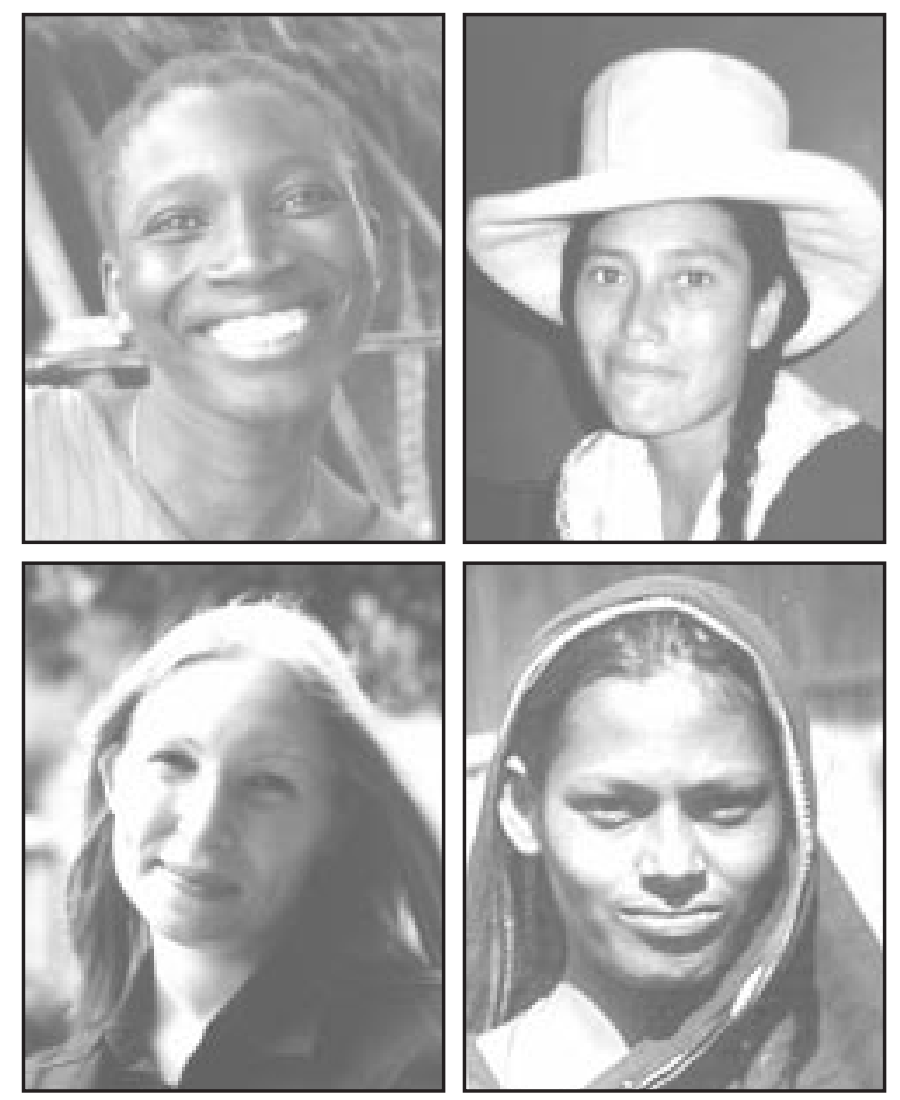

From Patna to Paris: Providing Safe and Humane Abortion

té/Quality/Calidad/Qualité/6 
Q uality/Calidad/Q ualité, a publication of the Population Council, highlights examples of clinical and educational programs that bring a strong commitment, as well as innovative and thoughtful approaches, to the issue of high-quality care in sexual and reproductive health. The series is based on the philosophy that people have a fundamental right to respectful treatment, information, choice, and follow-up from reproductive health care providers.

$Q / C / Q$ documents projects that are making important strides in one or more of the following ways: broadening the choice of methods and technologies available; providing the information clients need to make informed choices; enabling clients to become more effective guardians of their sexual and reproductive health; making innovative efforts to increase the management capacity and broaden the skills of service providers at all levels; combining health care, family planning, and related services in an innovative ways; and reaching underserved and disadvantaged groups.
Projects are selected for documentation by an Advisory Group made up of individuals who have a broad range of experience with promoting quality of care in sexual and reproductive health. None of the projects documented is being offered as a model for replication. Rather, each is presented as an unusually creative example of values, objectives, and implementation. These are "learning experiences" that demonstrate the self-critical attitude required to anticipate clients' needs and find affordable means to meet them. This reflective posture is exemplified by a willingness to respond to changes in clients' needs as well as to the broader social and economic transformations affecting societies. Documenting the critical choices these programs have made should help to reinforce, in practical terms, the belief that an individual's satisfaction with sexual and reproductive health services is strongly related to the achievement of broader health and population goals.

\section{Population Council}

The Population Council is an international, nonprofit, nongovernmental institution that seeks to improve the well-being and reproductive health of current and future generations around the world and to help achieve a humane, equitable, and sustainable balance between people and resources. The Council conducts biomedical, social science, and public health research and helps build research capacities in developing countries. Established in 1952, the Council is governed by an international board of trustees. Its $\mathrm{N}$ ew York headquarters supports a global network of regional and country offices.

Population Council, O ne Dag Hammarskjold Plaza, N ew York, N ew York 10017 USA

tel: (212) 339-0500, fax: (212) 755-6052, e-mail:qcq@popcouncil.org, http://www.popcouncil.org.

Publication of this edition of Quality/Calidad/Q ualité is made possible by support provided by the Robert H. Ebert Program on Critical Issues in Reproductive Health of the Population Council, by the Ford Foundation, and by the Gender, Family, and Development Program of the Population Council. Statements made and views expressed in this publication are solely the responsibility of the authors and not of any organization providing support for $Q / C / Q$. Any part of this document may be reproduced without permission of the authors so long as it is not sold for profit.

Cover photographs by (clockwise from top left): Debbie Rogow, Susan Wood, UNICEF, and Karen Tweedy-Holmes. The photo on page 1 was selected from M/MC Photoshare at www.jhuccp.org/mmc. Number Eleven 2001 ISSN : 1097-8194

Copyright $\odot 2001$ The Population Council, Inc. 


\title{
Introduction
}

\author{
by Carmen Barroso
}

For millennia, women and girls have found themselves facing unwanted pregnancies; across time and culture, they have often turned to abortion. Today, an estimated 46 million pregnancies each year are terminated by abortion (AGI 1999). They are induced for a wide variety of reasons, including economic factors; personal circumstances such as an absent partner or unfinished schooling; health considerations; and social and cultural factors. ${ }^{1}$ The decision to terminate a pregnancy may be simple and straightforward or more complex and difficult, depending on the client's social, legal, and personal context. But abortion remains the last measure of control women and girls have over their fertility, providing "respite and tremendous relief when performed under appropriate conditions" (Londoño 1989).

When performed by a trained provider with the appropriate equipment or drugs, abortion is a safe, low-risk proce-

\footnotetext{
${ }^{1}$ For example, in some settings where gender bias heavily favors sons over daughters, couples have sought diagnostic tests to determine the sex of the fetus and subsequently abort female fetuses.

2 Recently, safe and effective medical abortifacients have expanded women's options in some parts of the world. Medical abortion refers to termination with a medication that promotes the body's expulsion of the pregnancy without surgical intervention. This ranges from the clinically monitored, safe, effective use of mifepristone and misoprostol to the self-prescribed use of drugs such as misoprostol (Cytotec) alone in countries where safe, legal abortion is not available. Misoprostol users may well end up seeking hospital care to complete the abortion, since the selftreatment often triggers bleeding without sepsis or provider contact, thus allowing the user to avoid serious legal or medical risks (Barbosa and Arilha 1993).
}

dure. ${ }^{2}$ Because of legal and social restrictions, however, safe and humane abortion is not always available; instead, millions of women and girls seeking to control their fertility resort to dangerous procedures. The most common medical complications of illegal or unsafe procedures include infection and hemorrhage. Data from Nigeria and Latin America (where legal restrictions make

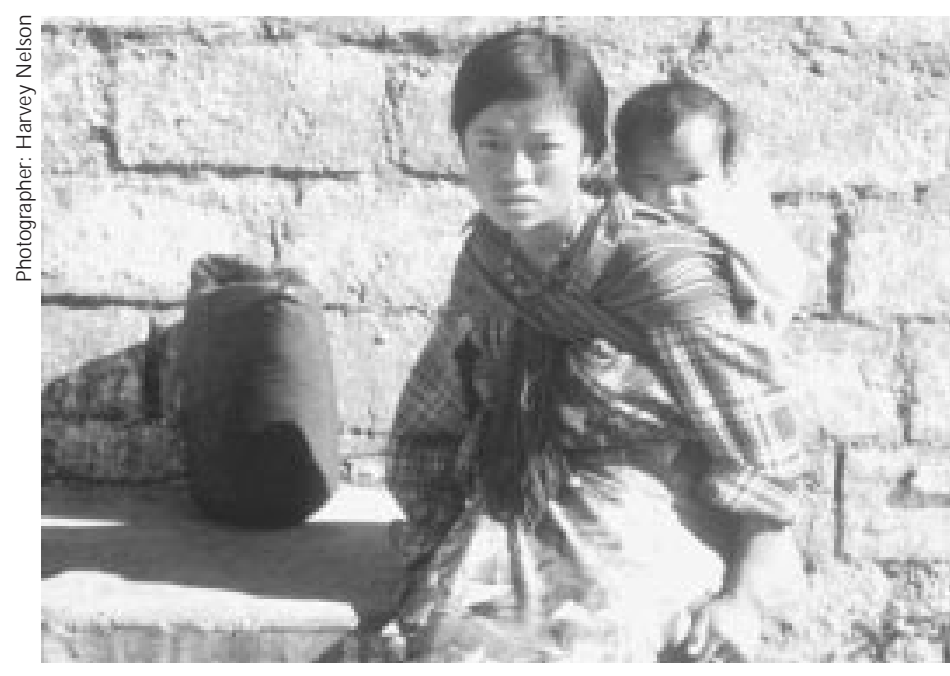

In the sixty minutes it takes to read this publication, nine women and girls on average will die needlessly as a result of poorly performed abortions.

access to safe abortion extremely difficult) suggest that 4 out of every 10 procedures result in severe complications; this risk is particularly grave for those in rural areas (Makinwa-Adebusoye et al. 1997; Singh and Wulf 1994).

Not surprisingly, millions of women and girls end up in hospital emergency rooms for treatment of complications after unsafe or incomplete abortion. For example, emergency rooms in Egypt alone treat 216,000 such women and 
girls per year, while the figure is 142,200 for Nigeria, 288,700 for Brazil, and 106,500 for Mexico (Huntington 1998; Henshaw 1998; Singh and Wulf 1994). Some never make it to the hospital: the fear of humiliating treatment and of legal recriminations, along with poverty and lack of access, undoubtedly deters many critically ill women and girls from seeking desperately needed emergency care.

In the end, unsafe abortion (and the immense personal suffering that may attend it) remains a serious global public health problem. As a result of botched procedures and the lack of accessible

\section{A bortion remains the last measure of control women and girls have over their fertility.}

and appropriate emergency care, 78,000 women and girls die each year unnecessarily; this avoidable loss accounts for no less than 13 percent of all pregnancy-related mortality (WHO 1998). In addition to the human cost, treatment of abortion complications constitutes a serious drain on health-sector resources.

With access to safe, legal abortion under severe constraint or debate in many parts of the world, less attention has been paid to the issue of quality of abortion care. Yet at the same time that millions of women and girls face abuse, grave morbidity, and risk of death in their quest to end an unwanted pregnancy, millions more terminate their abortions safely and with dignity. This issue of Quality/Calidad/Q ualité explores what it means-and what it takes- to provide an adequate level of quality in abortion care.

The following pages describe two programs that operate in very different settings but with a shared commitment to providing high-quality abortion care in a context of broader reproductive health services: the Clinique d'Orthogénie of Broussais Hospital in France and Parivar Seva Sanstha in India. Of course, both programs operate in legal climates that allow for safe services. But both have also brought a pioneering spirit to their work, introducing new abortion technologies and a range of reproductive health services that have expanded options and reshaped the design and delivery of care. In both programs, each woman or girl who arrives for abortion receives crucial basic care, including:

- Appropriate medical treatment to ensure complete abortion and safe recovery;

- If medically appropriate, choice about issues such as anesthesia and/or method of abortion;

- Supportive counseling;

- A range of related reproductive health services, including a choice of contraceptive methods to help her avoid another unwanted pregnancy.

Counseling is an especially important component of pregnancy termination care. With proper counseling, the decision to terminate a pregnancy can enable a woman to reflect upon her sexual relationship, her fertility intentions and behavior, and her own decisionmaking process. Such reflection "can facilitate or advance the process of acquiring personal awareness and identity as few other experiences can..." (Londoño 1989). An important part of the success of both the Broussais Hospital clinic and Parivar Seva Sanstha rests on the selection and training of staff who believe that having an abortion is an opportunity to protect one's 
health and to move forward in one's life- not a time to suffer.

of course, even emergency room providers who see women only for postabortion care can offer crucial nonjudgmental support and contraceptive counseling. Particularly if securing an abortion has been made into a frightening or unsafe experience, clients may be vulnerable to making inappropriate or unrealistic decisions about contraception. For example, many girls say they will "never have sex again," and therefore resist the idea of contraception, leaving themselves unprepared for their next sexual encounter. Women hoping to avoid a repeat experience may accept a longterm or even permanent method that they would otherwise not choose. Special post-abortion counseling materials, such as those developed by Ipas, are enabling more programs to approach this task with sensitivity and effectiveness.

The following articles provide concrete descriptions of the programmatic elements that enable the Broussais Hospital Clinic and Parivar Seva Sanstha to provide the kind of care they believe all women deserve-whether in the North or South, whether arriving for surgical abortion, medical abortion, or treatment of complications: the best available medical care, a range of service options, and nonjudgmental emotional support. The lessons from these programs are particularly poignant when contrasted with what we know about the avoidable experience of their less fortunate sisters.

\section{References}

Alan Guttmacher Institute. 1999. Sharing Responsibility: Women, Society and Abortion Worldwide. New York: AGI.

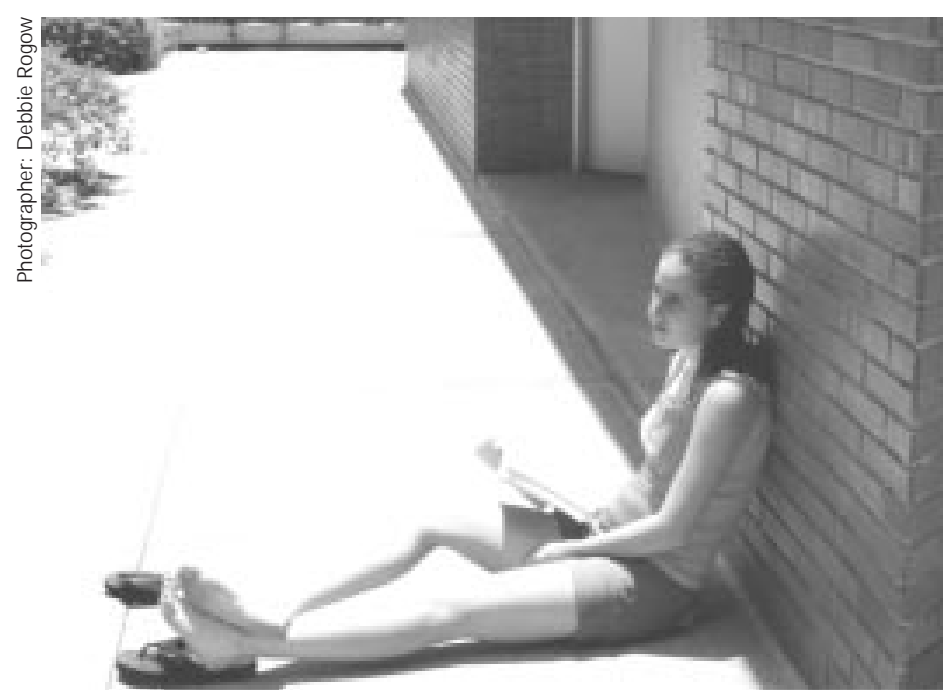

Each year, 46 million women terminate unwanted pregnancies. In proper settings, they can do so safely and with dignity.

Barbosa, Regina Maria and Margareth Arilha. 1993. "The Brazilian experience with Cytotec," Studies in Family Planning 24(4): 236-240.

Division of Reproductive Health, WHO. 1998. Unsafe Abortion: Global and Regional Estimates of Incidence of and Mortality due to Abortion, with a Listing of Available Country Data, third ed. Geneva: WHO.

Henshaw, S.K., et al. 1998. "The incidence of induced abortion in N igeria," International Family Planning Perspectives 24(4): 156-164.

Huntington, D., et al. 1998. "The postabortion caseload in Egyptian hospitals: A descriptive study," International Family Planning Perspectives 24(1): 25-31.

Londoño, M.L. 1989. "Abortion counseling: Attention to the whole woman," International Journal of $G$ ynecology and $O$ bstetrics, supplement 3: 169-174.

Makinwa-Adebusoye, P., S. Singh, and S. Audam. 1997. "Nigerian health professionals' perceptions about abortion," International Family Planning Perspectives 23(4): 148-154.

Singh, S. and D. Wulf. 1994. "Estimated level of induced abortion in six Latin American countries," International Family Planning Perspectives 20(1): 4-13. 


\title{
The Clinique d'Orthogénie at Hôpital Broussais, Paris
}

\author{
by Martha Brady and Batya Elul
}

For much of the last century, access to abortion in France was highly restricted, permitted only if the woman's life was at risk. Individuals aiding or abetting women in obtaining an abortion and individuals providing abortion could face a large fine and a prison sentence of up to five years. In the mid-1970s, the political climate began to shift. In 1975, 343 women, including many prominent writers and actresses, published a statement declaring that they had had abortions. A group of providers signed a letter stating they had performed abortions and women staged demonstrations calling for legal reform. Support also came from within government, as courts declared that they could no longer enforce the law. Further, Minister of Health Simone Veil acknowledged that it was impossible to prevent a woman who was determined to end her pregnancy from having an abortion and, consequently, that it was better to offer her medical aid than to risk her life or future fertility

Shortly thereafter, abortion-interruption volontaire de grossesse-was legalized in France. Initially, the law was fairly restrictive: the procedure was allowed only through ten weeks of pregnancy; public hospitals were not required to provide the service; minors had to secure parental consent; foreigners had a three-month minimum residency requirement; and all clients had to meet with a social worker and undergo a one-week waiting ("reflection") period before having the procedure. In 1982, in response to a shortage of physicians willing to perform abortions, the law was amended to require all public health facilities to offer this service; this new legal mandate led to the establishment of the Clinique d'O rthogénie at Hôpital Broussais. In 2001, many of the remaining early restrictions were lifted. Abortions may now be performed through the twelfth week of pregnancy; a minor may seek permission from an adult other than her parent; and the residency requirement and mandatory waiting period have been removed. However, for most of its history, the Broussais Clinic operated under the more restrictive conditions.

\section{The Clinic Opens Its Doors}

The Clinique d'O rthogénie at Broussais Hospital, one of 50 public hospitals in Paris, was opened in 1983 to conform to French law requiring that all public-sector hospitals offer abortion services. No other gynecological services were offered at the facility, and the hospital director opposed provision of abortion; to abide by the new law, however, he created a separate abortion clinic-the Clinique d'O rthogénie. 
Considering that the Broussais H ospital director's decision to provide abortion was originally based on a legal mandate rather than on a political commitment to women's rights, the evolution of the clinic's philosophy is inspiring. Indeed, the clinic has become a shining example of care shaped specifically to respond to the needs of its clients. Today, the clinic not only offers a range of abortion services but has also expanded its mandate to address a wide range of reproductive issues.

Located in metropolitan Paris, the Clinique d'O rthogénie serves primarily women residing in the city and its southern suburbs, although women from elsewhere in France may use the clinic's services. In 1997, for example, while 60 percent of all abortion clients lived in Paris, over 33 percent resided in the suburbs, and 2 percent came from other regions of France. The client population is diverse both ethnically and in terms of socioeconomic status, e.g., immigrants living in France for at least three months are eligible to use public services.

From its establishment in 1983 until 1996, the Broussais Clinic was under the direction of Dr. Elisabeth Aubény. Dr. Aubény began practicing gynecology in 1962 and had a distinguished record based on more than 30 years in both public- and private-sector reproductive health programs. At the time of her appointment to the abortion service, she had been working as a gynecologist in another hospital within the same university medical system as Broussais. Dr. Aubény's dynamic leadership set the tone for the clinic's work. She participated in the first clinical trial of mifepristone (also known as RU 486), work that led to the country's official authorization of the drug in 1988 and for which she is now well known, both in France and internationally.

Dr. Aubény's vision of quality reproductive health care is grounded in a desire to help individuals achieve their reproductive goals, and her approach is based on the principle of respect for women and their ability to make their own decisions. She stresses that high technical quality in itself is not sufficient. Rather, it must be coupled with a commitment to listen to clients and to learn about their personal and emotional experiences, as well as their immediate reproductive problems. Since Dr. Aubény retired in 1996, the clinic has been under the direction of Dr. Isabelle Dagousset, who shares her predecessor's commitment, energy, and vision.

\section{Individualized Care Starts at the Initial Contact}

Women hear about the Broussais clinic and its services through a variety of sources, including public service an-

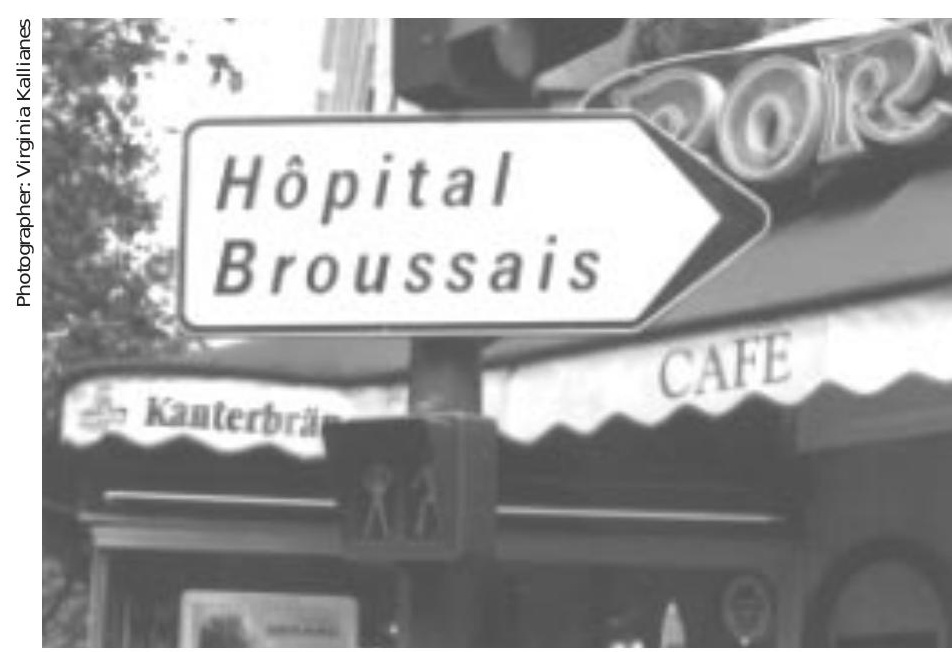

The Broussais Hospital opened an abortion clinic in 1983, when the French government required all public hospitals to provide this service. 
nouncements, media coverage, and referral from other providers, as well as from friends or family members. Some women arrive for scheduled appointments; others come seeking information and then make appointments. For most clients, the first point of contact they have with the clinic is by telephone, and the staff believe that the telephone encounter plays a critical role within the delivery of services. To back up this view, the clinic has developed a comprehensive training program of no less than 160 hours for all staff members responsible for answering the telephone and providing information. This intensive investment makes a difference. For example, Anne, the receptionist, has both the knowledge and the personal style that put women at ease. When women speak to Anne, they know they have reached a place where they will receive care.

On entering the clinic, clients are welcomed in a large and cheerful reception area, furnished with comfortable chairs, magazines, and flowers. tion, information is available on a range of topics related to reproductive health, including surgical and medical abortion; self-care after abortion; contraception; and sexually transmitted infections. Community notices and information about social services (including domestic violence and child care programs) are displayed on bulletin boards.

Clients are first greeted by one of the clinic's administrative staff, usually a receptionist. Depending on her particular needs, the woman may later meet with a social worker, a nurse, or a gynecologist-or all three. Moving from the reception area to the clinic's interior, one finds consultation rooms where women can talk with social workers, as well as fully equipped examination rooms, a surgical suite (where surgical abortions are performed), and designated waiting areas for women who are having medical abortions. In the surgical suite, daybeds are available for women to rest following surgery.

\section{Services Offered}

\section{The clinic has developed a} comprehensive training program of no less than $\mathbf{1 6 0}$ hours for all staff members responsible for answering the telephone. This intensive investment makes a difference.

Reflecting the clinic's commitment to information as part of the client-provider exchange, there are bright yellow pamphlets, clearly and concisely written, with information about services offered, operating hours, hotline numbers, and other practical details. In addi-
A small dedicated team of health care providers combine talents and strengths to provide an array of services. The clinic is staffed by 11 medical gynecologists: nine female and two male. This gender breakdown reflects a nationwide trend in the field of medical gynecology, where approximately 80 percent of medical gynecologists are female. ${ }^{1}$ The clinic also employs a part-time physician assistant, two psychologists, and various paramedical personnel. The paramedical staff includes a supervisor, two nurses, two secretaries, one nurse's

\footnotetext{
${ }^{1}$ In France, medical gynecology is a distinct specialty from obstetric/surgical gynecology. Medical gynecologists do not attend births or perform complex gynecological surgery.
} 


\section{Surgical A bortion}

Surgical abortions are provided through 12 weeks of gestation. Women electing to have a surgical procedure with local anesthesia arrive early in the morning, usually before 8:00 a.m., and typically are on their way home within three hours or by lunchtime. For many years-as has been the case in many countries where clandestine abortion is a recent memory-general anesthesia was initially an option for clients electing surgical abortion. H owever, in recent years staff agreed that local anesthesia was preferable, and clients are no longer given the choice to be put under general anesthesia.

\section{Medical Abortion: The Protocol}

Medical abortions are limited to gestations of seven weeks or less. Broussais was a pioneer site for the use of mifepris-

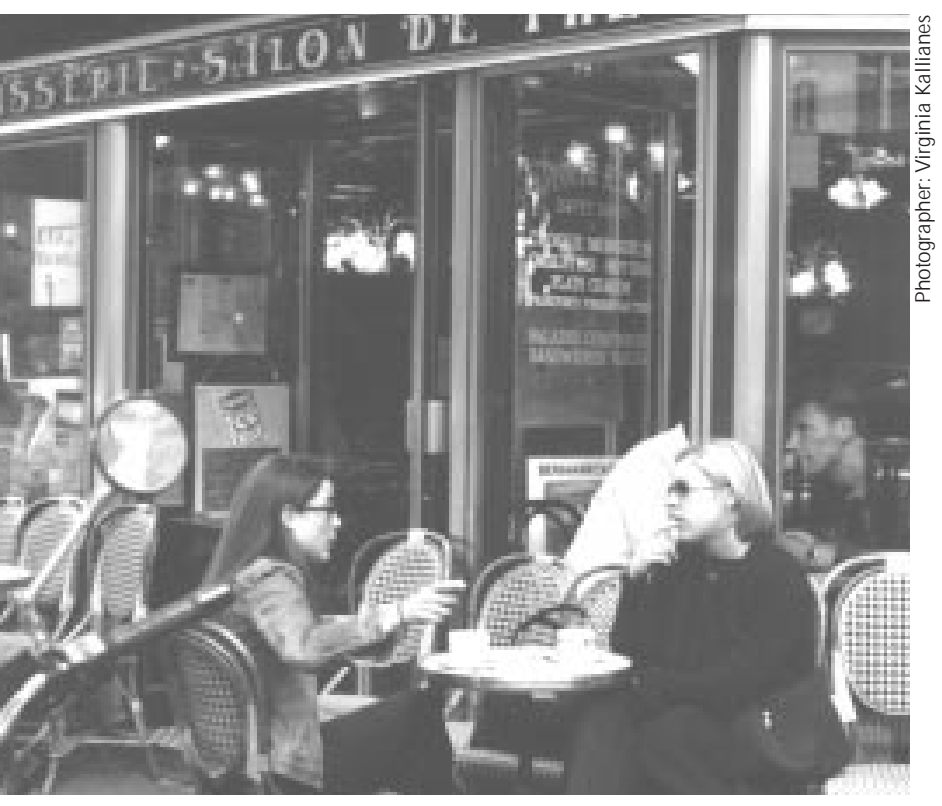

Women can go to the Broussais Clinic for contraception, STI testing and treatment, Pap smears, preliminary infertility care, and general gynecology, as well as for abortion. tone, also known as RU 486. The drug was first introduced in the clinic in 1983 as part of the manufacturer's research trials, and more than 20,000 Broussais clients have now undergone medical abortion. Currently, a majority of clients opt for this method; for example, in 1997, 715 underwent surgical abortion with local anesthesia while 1,081 had a medical abortion using mifepristone and misoprostol.

The counselor explains the process to each client step by step: how and when to take the different drugs, when she will begin to cramp and bleed, how to know when she expels, and what to do in the rare case she does not expel. She also counsels clients (and their partners, when possible) about contraception. For clients who elect to have a medical abortion, three clinic visits are required over a two-week period:

\section{Visit 1: Mifepristone}

At her first visit, the woman swallows three tablets (200 mg each) of mifepristone; by law, she ingests these tablets under the supervision of clinic personnel. At this time, she signs an additional informed-consent form designed by mifepristone's manufacturer. To accommodate women's schedules, a clinic nurse is available on Saturdays to provide this drug and the hospital's emergency room staff are available on Sundays. The client leaves a few minutes after taking the mifepristone. During the next few days, she may begin to bleed or spot.

\section{Visit 2: Misoprostol}

Clients return two days later to ingest misoprostol. The second visit is quite a bit longer than the first one. Unless the 
woman believes she has already expelled the products of conception and this is confirmed by a provider, she takes three tablets (200 $\mu \mathrm{g}$ each) of misoprostol orally. After taking the misoprostol, the woman remains for up to three hours in the clinic, where she may relax, walk around, or lie down in one of two comfortable post-observation rooms. (O ne of these rooms is for women and girls only; the second is designated for couples.) During this time, she will probably experience cramping and start to bleed and will probably undergo expulsion. Typically, women leave the Broussais Clinic as soon as they expel, even if far less than three hours have elapsed.

If a client wants to begin contraception, she can start the pill on the same day as her second visit. (Clients who want to use a different method are encouraged to use oral contraceptives for the first month and then return to the clinic or see their regular doctor to switch methods. However, the client has the final choice regarding her contraceptive method.) During the next two weeks or so, the woman will continue to bleed and might have some more cramping if she is still expelling products of conception.

\section{Visit 3: Follow-up}

About two weeks later, women return to the clinic for a follow-up examination. If a client did not undergo expulsion at the clinic on the day she took misoprostol, ultrasound is used to confirm the status of her abortion. For all other women, a clinical examination is performed and, if necessary, vacuum aspiration is used to complete the abortion. Success rates are extremely high, however; aspiration is needed in approximately 0.6 percent of the cases.
O ne client described her experience with medical abortion:

I just finished the $R U 486$ process and surprisingly enough, I feel very well; a few minor cramps, but a clear conscience. The $R U 486$ process of abortion was simple, easy, and comfortable. The only discomfort I experienced was slight nausea after ingesting the prostaglandin tablets, and no more than 45 minutes of cramps. The cramps, however, were very strong and uncomfortable, but passed eventually. Afterward, I expelled the contents of my abortion rapidly, without any discomfort or pain. It was very efficient.

I am grateful that I had the option of the RU 486 procedure. Taking pills orally in order to induce a natural abortion gave me peace of mind. I could not have comfortably experienced a surgical abortion, which would have given me great stress emotionally.

\section{Abortion Counseling: Autonomy, Support, and Reflection}

Although counseling is a key element of all services offered at the clinic, this aspect of care is particularly important in the abortion service. According to Dr. Aubény, the term "counseling" as used at Broussais goes beyond the exchange of information regarding the abortion method selected. It refers to providing the opportunity for women to discuss their concerns, experiences, and plans for future conception and contraception. Providing nonjudgmental support is key, e.g., not categorizing a woman as "good" or "bad" based on whether she used 


\section{Medical Abortion in Developing Countries}

One may ask whether the experience at the Broussais Clinic has any relevance to the delivery of services in developing countries. The answer is clearly yes. Over the past few years, several studies of mifepristone-misoprostol medical abortion have been conducted in developing countries. In one study, the French regimen was used by 799 women eight weeks pregnant or less in Cuba, China, and India [see the following section of this edition for a brief description of the Indian experience]. While success rates varied by site (China 91 percent, Cuba 84 percent, India 95 percent), nearly all women (84-95 percent) were highly satisfied or satisfied with their experience and, similarly, the vast majority (84-96 percent) reported that they would choose medical abortion again. Women consistently rated the avoidance of surgery, avoidance of general anesthesia, less pain, safety, ease, and compatibility with everyday responsi- bilities among the method's best features. Some women, however, did not like the bleeding they experienced with the method and felt that the abortion dragged on too long. Another study, employing a reduced dose of mifepristone and allowing women the option of taking their misoprostol at home (and consequently eliminating the most lengthy clinic visit), is concluding in Tunisia and Vietnam.

Another potentially promising method of medical abortion in developing countries entails the use of misoprostol alone. Misoprostol, marketed under the name of Cytotec, is inexpensive, does not require refrigeration, and is already available in over 60 countries for the prevention of ulcers. Several studies from Cuba show that this method may induce abortion in approximately 90 percent of cases. Studies are ongoing to determine the best regime for use of misoprostol alone. contraception, or on whether she has had previous abortions. As Dr. Aubény cautions, "We must remember that the women who have abortions are the same women who have babies, too!"

Dr. Aubény personally selected staff who share a common vision and commitment to women's health care. For example, Thérèse, who counsels medical abortion clients, spent many years of her professional life working in counseling services. She believes that her ten years of experience as a family counselor in Brazil helped broaden her understanding of the complexity of interpersonal relationships.

Christine, a nurse for over 30 years, worked for many years in emergency room surgery, where she witnessed firsthand the mortality and morbidity caused by illegal and unsafe abortion. Her professional experience, her concern for women, and her philosophy about this work, including an ideological belief in women's right to have safe abortions, psychological support, and counseling, led her to Broussais Clinic in 1988.

Francine is a social worker with expertise about a range of social services in Paris. She has seen that women's ability to solve their health problems is often tied to larger social or economic problems. Conversely, she has also seen that women who suffer these larger problems may be particularly vulnerable to an unwanted pregnancy. 


\section{Autonomy and Choice}

Autonomy, control in decisionmaking, and choice are the hallmarks of the client-provider transaction at Broussais. This posture begins with the first contact. It is the clinic's policy that women must take the initiative to seek abortion themselves, and the decision to have an abortion must be their own. Hence, the clinic does not accept initial phone inquiries made on behalf of a woman by her partner. The phone receptionists also pay attention to choice: to accommodate women's schedules, the clinic offers counseling sessions in both mornings and afternoons, five days a week.

Once the woman or girl arrives at the clinic, she meets with one of the three full-time counselors. The counseling sessions are intended to help women with decisionmaking on a variety of issues, including contraceptive or abortion method selection. A psychologist holds a weekly session in which women who are having particular difficulties deciding whether to terminate their pregnancy or who have had multiple terminations can explore issues of sexuality and decisionmaking in more depth.

Christine, reports that medical abortion clients experience autonomy in the sense that they are "in charge of the process." (Christine initially had some misgivings about medical abortion that, in hindsight, she believes she may have communicated to her clients; with time and experience, however, she became more comfortable with the method and believes it is an important option to provide.) Ultimately, all clinic staff members are committed to respecting individual choice, even when it some-

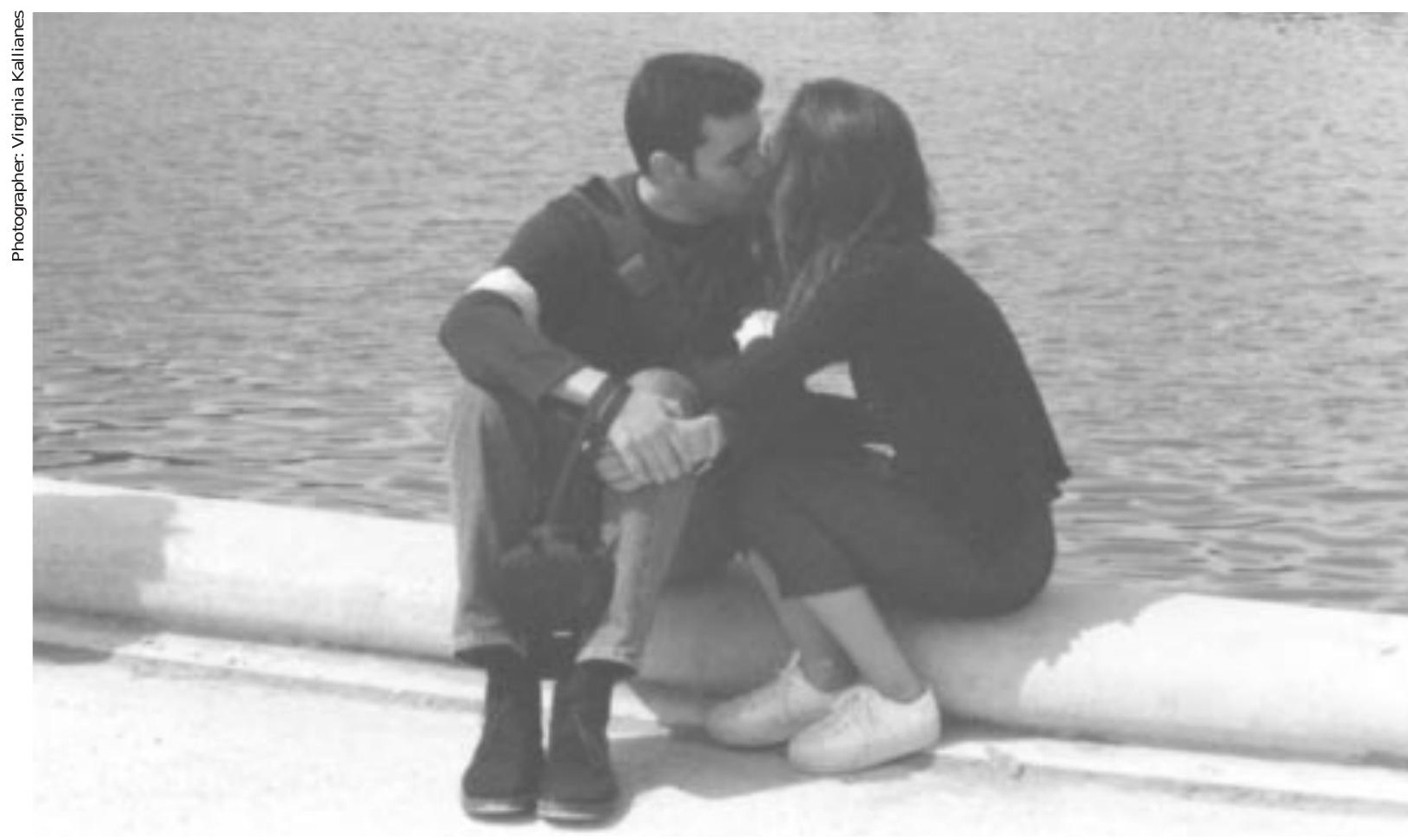

Partners are welcome at the Broussais Clinic, but women must make the initial phone contact themselves. Counselors also find that some women view the experience of abortion as an opportunity to reflect upon their personal and sexual relationships. 
times contradicts their own opinions. Virtually every staff member echoes this sentiment:

O ur purpose is to enable each woman to make the best choice for herself.

$$
\text { - Virginie, staff nurse }
$$

Our main purpose as clinicians is to organize ourselves so that women who decide to have an abortion can have one quickly and safely.

$$
\text { - Staff physician }
$$

In our clinic, the woman is in charge of the process of abortion. It is her abortion, and her choice is what is most important.

$$
\text { - Clinic counselor }
$$

We are here to adapt to each woman. Each woman is a special case for us.

$$
\text { - Clinic administrator }
$$

Or, as Dr. Aubény comments succinctly:

The best abortion for a woman is one that she has chosen for herself.

The staff understand that many women can assume greater autonomy when they feel they are in a supportive environment. $\mathrm{O}$ ften, part of that support may

\section{Engaging a girl or woman in a conscious decisionmaking process about her abortion procedure is sometimes an ouverture or opening to considering her options more broadly.}

come from a partner, friend, or family member. In keeping with the philosophy of empowering the woman to make decisions, it is the client who decides

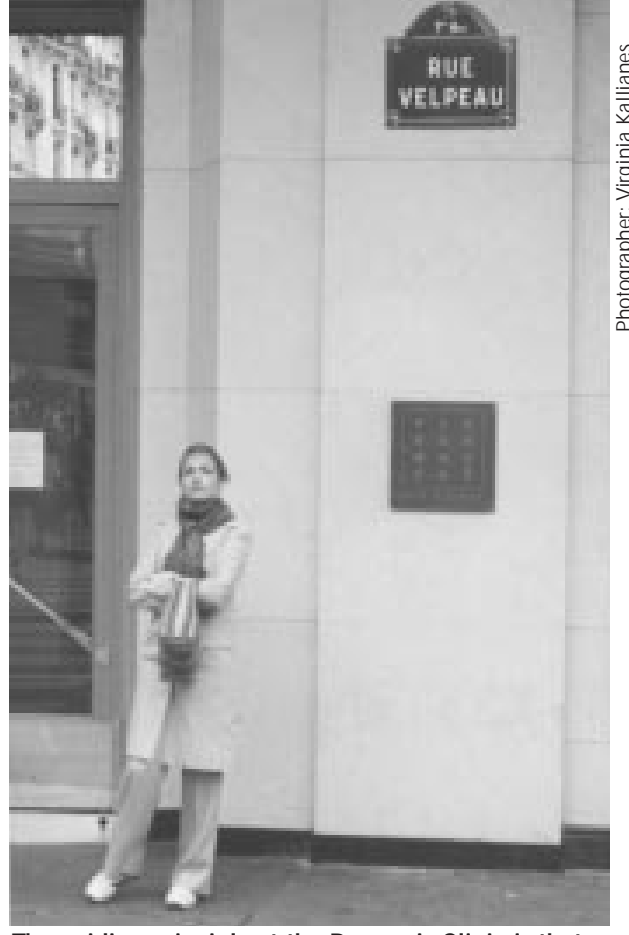

The guiding principle at the Broussais Clinic is that a woman be in charge of her own abortion decision. The counselor's job is to help her integrate the event into her life.

whether she wants her partner to be involved. For this reason, in 1994, a special room was built so that the partners, friends, or family of clients having medical abortions could join them during the waiting period; there are now separate waiting rooms for those women with partners and those who are unaccompanied. Staff members report that more and more women are bringing their partners, for both medical and surgical abortion procedures.

Of course, the staff understand that each woman or girl has different needs for information and for discussion, and that each woman must feel in control of her decision to engage in such discussion. Thérèse explains, "Counseling is a complex matter. $O$ ne has to start where and when the woman is ready. I am always available for women, but can only go so far with every woman. Each woman has a right not to speak as well as to speak." 


\section{Reflection and Growth}

The staff see that effective counseling can have unexpected benefits for the girls and women who come through the doors at Broussais. Abortion counseling at Broussais is clearly aimed at helping clients reflect upon and find meaning in the experience. As Christine explains, engaging a girl or woman in a conscious decisionmaking process about her abortion procedure is sometimes an ouverture or opening to considering her options more broadly. Jacqueline, a clinic nurse, adds, "We provide a link between the abortion experience and the future-the woman's future and future contraception. We help a woman integrate this event into her life."

Similarly, Thérèse has learned that the experience of facing an unwanted pregnancy can in some ways be a positive one for many women and girls. "Women must gain something by having this [abortion] experience," explains Thérèse. She offers an example: "For some women or couples, even though they have chosen not to proceed with the pregnancy, they are at least comforted in knowing that they are fertile."

Among those clients who select medical abortion, many consciously choose to view the products of conception, and this process seems to complement the counseling. According to Thérèse, this experience often provides a sense of relief that the abortion is complete, as well as an emotional sense of closure.

\section{Impact of Counseling on Effectiveness Rates}

$O$ ne of the most striking aspects of the medical abortion service at Broussais is the very high effectiveness rate, which has increased to 99 percent in the past few years. The staff members are convinced that the strides they have made in providing emotional and psychological guidance have contributed to this increase. Jacqueline, a staff nurse, explains that when women receive better care, they actually experience less tension, thus making the expulsion of the products of conception easier. Thérèse agrees that there are psychological aspects to the expulsion during medical abortion, agreeing, "Counseling helps improve the success rate of medical abor-

\section{The success rate for medical abortion has risen to 99 percent. Staff are convinced that the strides they have made in providing emotional guidance have contributed to this increase.}

tion because women who are more relaxed have an easier time." Further, she has observed that the group setting helps to provide encouragement for women to the expel products of conception.

\section{The Investment in Training Counselors}

Selecting counselors and staff members who share the clinic's vision of reproductive health care is important, but is not enough by itself to result in the kind of quality counseling that clients at Broussais receive. Complementing the 160 hours of training the telephone receptionists receive, each counselor receives 400 hours of specialized training. The cost for such counselor training 
is $28,000 \mathrm{FF}$ (or US $\$ 5,000$ ), a significant sum even for the Broussais Hospital. The staff feel that the benefits reaped from such counseling clearly make it a wise investment in the long term.

\section{Beyond Counseling: The $\mathrm{J}$ ob of the Social Worker}

Many women who come to the Broussais Clinic are young and single with children; often they are in precarious social and financial situations. Sixty percent of clients have problems negotiating financial payments and getting the proper paperwork filled out so that they can receive the benefits to which they are entitled. Francine, the social worker at Broussais Clinic, assists clients experiencing socioeconomic problems. She helps the women maneuver through the complex French health care bureaucracy so that all who need care can receive it. At times, this involves finding creative solutions to clients' problems. Although providing this type of social assistance to women is not obligatory in French public-sector clinics, the staff believe that this service is important or many women would-for logistical, bureaucratic, or financial reasons-be denied the services they need.

\section{Maintaining Staff Commitment and Morale}

Working at the Broussais Clinic is not easy. First, it is emotionally demanding to support women and girls as they confront not only an unwanted pregnancy, but also a range of related personal concerns. Further, because staff are personally invested in the well-being of their clients, it is sometimes difficult to stay neutral in the face of a woman's own choices. Dr. Aubény's comment reflects the moral framework that guides the staff in this regard:

O ne must always keep in mind that it is never easy for women to have an abortion. Our job is to offer the best choice for women by offering the best choice of services.... It requires a basic respect for each woman and a commitment to women's autonomy and their rights in decisionmaking.

It is also taxing to work in an abortion clinic in a setting where anti-choice activists seek to intimidate providers. Indeed, on three occasions from 1990 to 1995 , demonstrators chained themselves together outside the clinic walls to protest the services Broussais provides to women and girls. These attacks forced the staff to reflect on and discuss why they had initially chosen to work in an abortion clinic: largely, a personal commitment to abortion rights and/or to quality reproductive health care for women. In the end, the anti-choice attacks on the clinic actually solidified the bonds between staff members and increased their dedication to preserving women's right to choose abortion.

In addition to sharing a sense of commitment to the goals of the clinic, the clinic brings staff together on a regular basis. M onthly meetings provide the opportunity for education, training, and social interaction, and all staff, both medical and paramedical, are welcome to attend. Before the meetings get started, there is animated conversation, as the discussion touches on social matters (such as members' babies, husbands, and personal lives), or on larger social prob- 


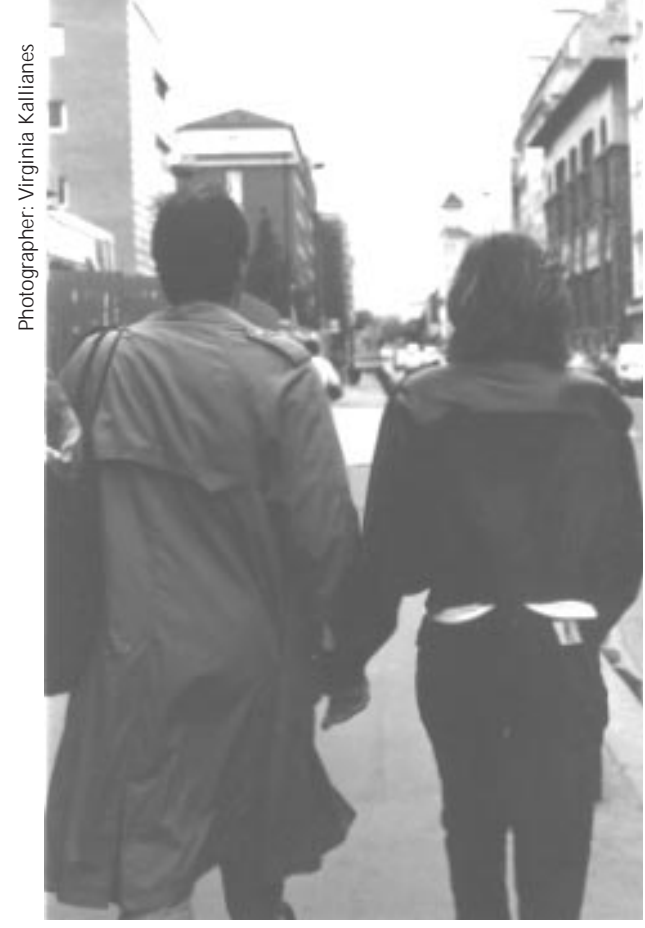

According to staff, quality rests in the details, and they are gratified when a client leaves saying, "Thank you for the day I spent at the Broussais Clinic."

lems (such as domestic violence, politics, and attacks on abortion clinics).

Generally, the monthly meetings focus on a particular substantive theme. This may be a clinical issue, such as pain management, or when to allow women to leave the clinic after taking misoprostol. Another focus might be a counseling concern, such as how to cope with dissatisfied or hostile clients. The meetings also provide a venue to review the educational materials, in which the staff members collectively consider how well the existing materials, which are prepared by the government, are meeting the evolving needs of their clients. Once there is consensus about what new material to produce and what the content should be, a subset of staff members will design the materials. ${ }^{2}$

Such consensus is part of the management style at the clinic. Typically, decisions are initially generated at the management level. However, they are subsequently discussed with all staff members at the monthly staff meetings or at a special meeting to achieve group consensus.

Clearly, working at the clinic signifies shared commitments, staff unity, and opportunity for professional development. The staff members get a great deal of support from each other, and a strong sense of collaboration is evident throughout the clinic. As one counselor said, "Here we are a real team. We have a sense of being a team and women sense the unity of our provider group." All of this helps explain why most staff members say that they do not experience burnout.

The most satisfying reward, however, comes from the women and girls for whom the staff provide care. As one staff physician put it, "People always want numbers," but it is important to understand how the success has come about, one woman at a time. "It is in the details that you arrive at the essentials." At the Broussais Hospital Clinique d'O rthogénie, the staff achieve the final measure of success when clients say, "Thank you for the day I spent here." Toward that end, they undertake an enormous effort day after day to give meaning to the guiding words of Dr. Aubény:

Women have a right not only to abortion. They also have a right not to suffer.

\footnotetext{
${ }^{2}$ As part of a broad information and education campaign, the French health authorities have provided much of the general information about clinical procedures and contraceptive methods. Recognizing the need for supplementary materials, the clinic staff has started to develop some of its own documents. While funding for production and printing is covered by the hospital, the clinic staff maintains control of the content, layout, and design.
} 


\section{Lessons Learned}

It is not surprising to find high-quality, woman-centered reproductive health services in France today. Nor is it surprising to learn that women in France have access to a range of fertility-regulating technologies. What is particularly noteworthy about the Broussais Clinic is the way in which these services are offered. The goal is not simply to perform a procedure correctly, but to empower women to make decisions about what services they need, about the technology they want to use, and about the quality of their overall health and lives. While many of the service elements found at Broussais are unique to that clinic, there are universal themes that have a much broader application.

1. Particularly with sensitive services such as abortion, hiring staff who share the mission and purpose of a program is key to ensuring stability and quality of care. In the case of the Broussais Clinic, providers draw strength from their shared commitment not only to abortion rights and quality of care, but also to the autonomy of the client with respect to the interests of the provider.

2. High-quality care requires investments in training far beyond that which is typical of many programs. At the Broussais Clinic, this comprehensive training extends to staff who answer the telephone (and who can influence a client's decision about service use) and those who work in the reception area. W hat appears at first to be a startling up-front investment in training has paid off in satisfaction among both staff and clients.

3. With proper counseling, women are comfortable with being more directly involved in the abortion experience, whether deciding about the method of abortion or, for the majority who opt for medical abortion, expelling and viewing the products of conception. Engaging clients in an active process of reflection and autonomous decisionmaking can actually lead to personal growth for many women and girls experiencing unwanted pregnancy.

4. As a simple and safe procedure, and as the final measure of control a woman has over her fertility, surgical and medical abortions have a critical role in women's overall reproductive health services. Ensuring its proper place in comprehensive care is a challenge for providers, health service delivery systems, policymakers, and women's health advocates. 


\title{
Parivar Seva Sanstha, India
}

\author{
by Shelley Clark \\ Sneh Vishwanath \\ Sunanda Rabindranathan
}

Most reproductive health programs hope to provide and maintain high-quality, affordable, and accessible care. However, precisely in the settings where the unmet needs are greatest, resources for facilities, supplies, and personnel are often most limited; when the service being offered is as personally or politically sensitive as abortion, programs face an added challenge in protecting the dignity of both clients and providers. Indeed, many organizations facing such financial and social dilemmas have resigned themselves to lower standards or have simply dissolved. In this context, the story of Parivar Seva Sanstha in India is a particularly inspiring and useful example of how innovation can overcome adversity.

\section{An Overview of Abortion Provision in India}

India was the first country in the world to adopt a national family planning program, in the hopes of reducing population growth rates. The government of India presented its first five-year plan to limit family size and control population growth in 1952. However, because the only method widely provided was sterilization, the proportion of couples using contraception began to stagnate. In fact, by 1970 about 70 percent of those with an unmet need for family planning were younger couples who wanted spacing methods. W ith little access to temporary methods, a large number of these women had unwanted pregnancies. Many resorted to backstreet and illegal abortions.

In 1972, Parliament passed the Medical Termination of Pregnancy Act, which granted women the legal right to terminate an unwanted pregnancy on liberal social and socio-medical grounds. Unfortunately, although women have retained their legal right to abortion, almost 30 years later many still lack access to safe, affordable, and licensed abortion providers. There are several reasons why women do not use legal abortion services in India. First, many women and girls are unaware that abortion is in fact legal. Second, there are too few trained abortion providers and basic facilities. As a result, despite its legal status, as many as 80 percent of the abortions provided in India are performed in the "backstreet" offices of unlicensed providers (Chhabra and N una 1993). Some of these unlicensed providers offer relatively safe procedures in their private of-

\section{In Memory of Dr. Sneh Vishwanath}

We dedicate this article to our co-author, Dr. Sneh Vishwanath, Medical Advisor to Parivar Seva Sanstha, who died on 4 J une 2001 after a brief illness. Sneh was an exceptional person. Through her research and service delivery activities, she helped ensure that highquality, affordable, and accessible services were provided to women. Her contribution to PSS and to Indian women is acknowledged with deep gratitude. 
fices but charge exorbitant rates. However, for most women in India, particularly those living in rural areas, safe, affordable, and high-quality abortion is still unattainable.

\section{The Founding of Parivar Seva Sanstha}

To tackle the growing problems of its floundering family planning program and inadequate safe abortion services, in 1976 the government of India called for greater involvement of voluntary organizations. Dr. Sudesh Bahl Dhal, an obstetrician-gynecologist from Delhi, responded to this call, founding an organization dedicated to providing safe and affordable abortion services. This new organization became affiliated with M arie Stopes International, a worldwide organization based in London that now works in more than 32 countries around the world.

Dr. Dhal opened the doors of the first clinic in Delhi in 1979, under the Marie
Stopes name. In the hopes of lessening the stigma associated with abortion, she boldly heralded the event with overt media campaigns advertising safe abortion services offered with warmth and care. The clinic, like many abortion services around the world, quickly found it was meeting a very real need. As more and more patients sought out their services, additional Marie Stopes clinics were opened throughout India and the service offerings widened beyond abortion. As the organization grew to have a national reach, it changed its institutional name to Parivar Seva Sanstha (PSS), meaning Family Helping O rganization; the clinics, however, continued to operate under the name of Marie Stopes.

\section{Abortion Care at PSS}

Despite limited resources, Parivar Seva Sanstha's commitment to offering care that is friendly, safe, affordable, and efficient remains paramount. For the client, this begins when she enters the clinic,

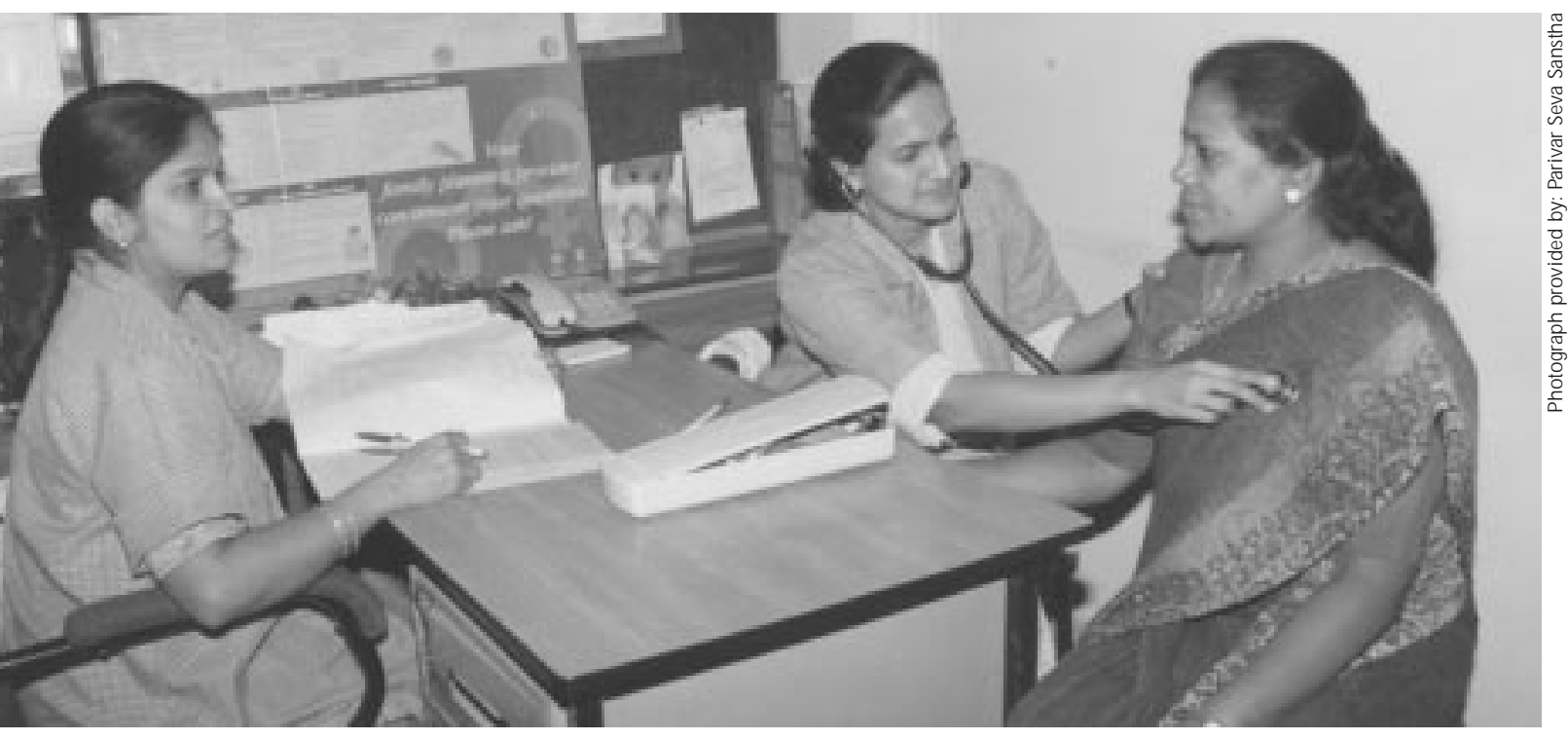

The first aim is to put the client at ease and encourage her to ask questions. This is particularly important because many clients are reluctant to speak frankly in front of a doctor, especially if there are large gaps in social status. 
typically located to allow easy access, by passing through the now-famous arches signifying the entry to a PSS facility. She is welcomed by a counselor, who confirms and records the reason for her visit, and asks her to take a seat. Because the personalized care delivered at PSS frequently results in moderate delays, clients usually spend 15 minutes in the waiting area before being called in for an individual counseling session.

Staff take particular pride in the physical appearance, comfort, and cleanliness of the clinics. In a typical clinic, the orderly reception area is furnished with chairs, a television, magazines, and toys for children, along with informational brochures in the local language (or with pictures only), posters describing methods of contraception, and a jar of free condoms. As one client straightforwardly explained, "W hat I like about PSS is the sitting space. I had an abortion before at [another] clinic; but here it is big and spacious."

\section{Preabortion Counseling and Support}

Counseling is considered one of the most important components in service delivery, and confidentiality is a hallmark of that process. Although the clinic is often crowded, counseling takes place in a private room or semi-private curtainedoff enclosure. All information exchanged during this session is strictly confidential. The case histories of the clients are kept under lock and key, and neither the client's name nor the procedure for which she is admitted to the clinic is divulged to any outsider. Indeed, women often remark that they chose PSS because they were confident that their visit would not become the talk of the town.
The quality of the counseling is also of paramount importance. Individual preabortion counseling typically lasts about ten minutes. The first aim is to put the client at ease and encourage her to ask questions. The counselors take pains to establish rapport and to alleviate nervousness. If the woman wishes, her hus-

\section{Confidentiality is a hallmark of the counseling process. Case histories are kept under lock and key, and neither the client's name nor the procedure for which she is admitted is divulged to any outsider.}

band or other relatives may join the counseling session. Information is presented using nontechnical terms, and every effort is made to have staff who can speak to clients in their local languages, which is critical as many women are not fully conversant in or comfortable with English or Hindi. Counselors probe the client's knowledge of reproductive health and family planning before explaining the various choices available to her. O ne counselor explained that some clients are reluctant to speak frankly in front of a doctor, especially if there are large gaps in social status.

The counselor then takes a personal and medical history. According to the counselors, nearly all of the women have made up their minds about wanting an abortion before arriving at the clinic; most wish to terminate pregnancy for one of two reasons: either they already have their desired number of children and do not want any more, or 
they became pregnant while lactating, and their current child is too young. In rare cases of uncertainty, the counselor encourages the woman to discuss her situation and examine her options. The counselor explains the abortion procedure and the use of any pain medications, as well as any potential complications. The woman then signs an informed-consent form.

Available contraceptive options are also explained during this counseling session and emphasis is given to the importance of using contraceptive methods to avoid another unwanted preg- nancy. If, as is often the case, the husband is present and supports the abortion decision, the counselor consults the client about inviting her husband in for contraceptive counseling. The husband's presence can be important, as it is often he who ultimately makes decisions about contraceptive use.

\section{The Abortion Procedure}

To date, only surgical abortion is available at PSS clinics. Equipment and supplies vary according to local conditions, but a typical clinic has two operating

\section{Medical Abortion at PSS and in India}

Given the leadership of PSS in the introduction of manual vacuum aspiration in India, it is not surprising that the organization is eager to become the first nongovernmental organization in the country to offer medical abortion services. Although mifepristone (RU 486) has not yet been approved in India as an abortifacient, India was one of the first countries in the developing world to offer medical abortion through clinical trials. In 1991-93, the Population Council conducted a trial at K.E.M. Hospital in Pune, in the state of Maharashtra, using the French regimen (described in the first part of this report); the trial demonstrated that this option was safe and highly acceptable to Indian women. This study was followed by a similar trial using the French regimen that offered access through a variety of providers, including the research hospital in Pune, a family planning clinic in Mumbai, and a rural health station located outside Pune. The most recent study, conducted by the All India Institute of Medical Sciences, gave women a lower dose of mifepristone (200 mg) rather than the standard French dose of $600 \mathrm{mg}$ and found the reduced dose to be equally effective in producing complete abortion.

PSS is about to embark on several mifepristone trials, which aim to make this method more affordable, practical, and acceptable to their clients. The government's Ministry of Health and Family Welfare has approved a study of women seeking termination of pregnancy up to 56 days using (a) mifepristone, followed by misoprostol; and (b) misoprostol alone. PSS plans to conduct trials in four clinics (two in Delhi, one in Agra, and one in Jaipur), demonstrating that NGOs can safely and effectively provide this new option. ${ }^{1}$ As in the French regimen, women who request a termination of pregnancy will receive a general checkup and be screened for eligibility. If the woman is in good health, has no contraindications, and is within the predefined gestational age limit, she will be given full information about both surgical and medical options and asked to choose between the two. Unlike the French regimen, how-

\footnotetext{
${ }^{1}$ Although PSS has completed the development phase of the project, implementation awaits approval for PSS to import the drug.
} 
theaters: one for early, simple abortions (which constitute the vast majority of procedures), and the other for early procedures performed with concurrent sterilization and for all second-trimester procedures. On average, about ten procedures overall are carried out during a clinic session.

Eighty-five percent of all procedures are carried out in the first trimester (before 12 weeks of gestation) and almost all are performed by manual vacuum aspiration (MVA). ${ }^{2}$ PSS was among the first to bring MVA to India 23 years ago, and over the last five years this method has become increasingly popular for early abortion. To meet the growing demand, PSS has helped organize and conduct MVA training of medical practitioners in their clinics. By introducing MVA, PSS has been able to increase significantly the number of

\footnotetext{
2 M VA involves using a hand-held syringe attached to a cannula to suction the contents of the uterus and is used to induce abortion in women up to 12 weeks of gestation. MVA completely evacuates the uterus in more than 98 percent of clients and can be performed on an outpatient basis using local anesthesia. Although electrical vacuum aspiration is equally effective, it requires a constant source of electricity.
}

ever, which restricts access to women with gestation up to 49 days LMP (i.e., the first day of her last menstrual period occurred no more than 49 days ago), the protocol to be used by PSS will offer mifepristone to women up to 56 days LMP.

Women who are eligible and who choose to participate in the study will take the first drug, mifepristone, in the clinic at the reduced dose (200 mg). Since mifepristone tablets are relatively expensive to produce and the previous study found the lower dose did not result in diminished efficacy, this regimen will make the method more affordable and therefore accessible to women with limited financial resources.

Finally, in contrast to all previousmifepristone trials in India, women will be given the option of either returning to the clinic two days later to take $400 \mu \mathrm{g}$ oral misoprostol or taking misoprostol at home. Previous trials in Vietnam and Tunisia demonstrated that over 85 percent of women preferred to take the misoprostol in the comfort and privacy of their own home. All women will also be provided with instructions on how to reach a health care provider promptly with any concerns or questions. Approximately two weeks after taking the first drug, women will return to the clinic to have the completion of the abortion assessed by manual exam or ultrasound, depending on current clinical practices. Special efforts will be made to contact women who do not return for their follow-up visit.

PSS providers are enthusiastic about the prospect of providing this method. The head doctor at one of the clinics, Dr. Sandeep Suri, lamented that medical abortion is not yet available at their clinic, as she feels that many women fear surgery and the risk of infection and, therefore, would eagerly choose mifepristone. In addition, she notes that many Indian women come to the clinic asking, "Is there no medicine for abortion?" They have already heard about abortifacient drugs through informal channels. For example, local newspapers have recently run stories about medical abortion and several staff members have heard that mifepristone (probably smuggled in from China) is available on the black market in India. Dr. Indu Kulshreshtha concurs with Dr. Suri's eagerness to offer medical abortion, noting, "Satisfaction is always higher with choice; this is as true for abortion procedures as it is for contraceptive methods." Providers generally agree, however, that counseling is essential to find the best method for each woman. 


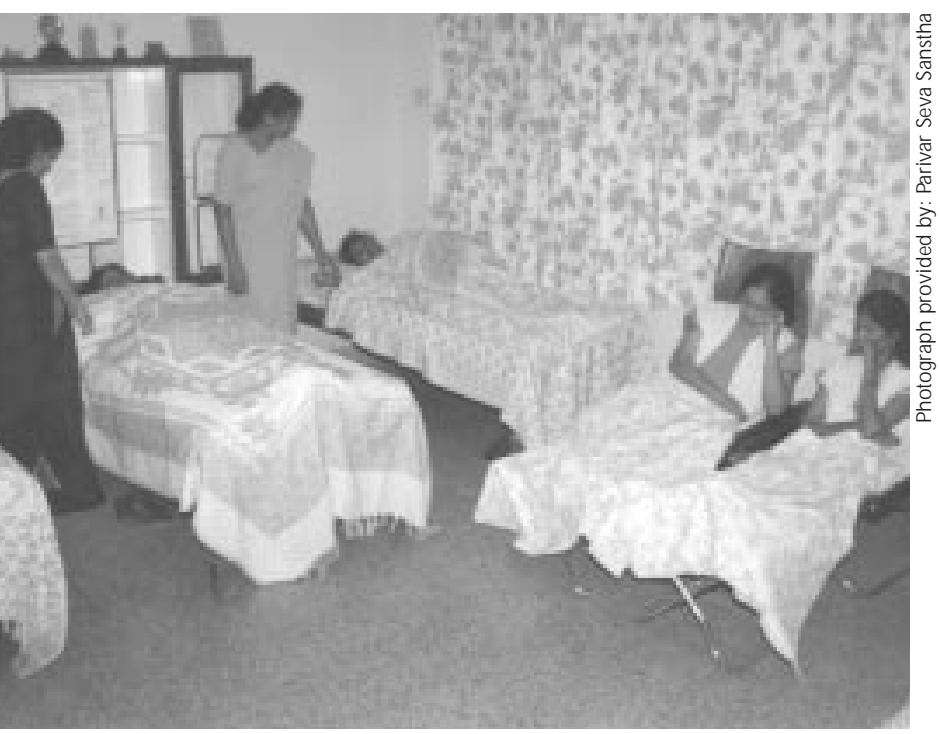

Women who undergo a simple MVA generally recover after 10-15 minutes. Those who have a simultaneous tubectomy have a longer resting period. sedative. However, depending on the physician and the emotional state of the woman, a few procedures are carried out under general anesthesia; an anesthesiologist is generally available to work at the clinic on an as-needed basis for this purpose.

A woman who requests a tubectomy may have the sterilization performed concurrently with first-trimester abortion; the double procedure is normally carried out under local anesthesia or sedation.

\section{Postabortion Care}

After the abortion procedure, women move to the recovery room and rest on recliners or beds. The resting period is generally 15-20 minutes after an MVA, or longer for those women who have received general anesthesia. While the clients rest, staff again review both postabortion care and (if appropriate) contraception. Staff members report that about 60 percent of women accept some form of contraception concurrent with or immediately subsequent to the abortion. A further 10 percent accept it when they return for a follow-up visit. The most popular long-term method is an IUD, while the most common spacing methods are oral contraceptive pills and injectables.

\section{Client Satisfaction}

Most women hear about PSS from a trusted friend or family member, or are referred by other health care facilities. Some are even referred by public-sector clinics that provide abortion but advise clients that "PSS has better services." $M$ any select PSS because of its relatively affordable fees. But almost universally, clients also arrive with the expecta- 
tion that PSS will provide friendly, safe, and efficient abortion services. In general, comments from clients are a testimony to their satisfaction with the experience:

I was a little nervous about the operation, but the staff were so cordial that I felt at ease. I feel very happy with the services.

I have been married only recently and don't want to have a child yet. I want to plan my family. My neighbor had used the Marie Stopes service and recommended it to me. The best thing was the attitude of the staff. They were warm and friendly and boosted my confidence when I was apprehensive about the procedure.

Two years ago I had undergone an abortion by the local dai [midwife]. I was not satisfied with the experience I had with the dai. PSS was different because the atmosphere was very warm and the staff were very polite to me. Also, the dai had carried out the operation at her house. [At] PSS, the staff were very professional.

Asked what they liked least about the clinic or what ideas they had for improving the services, clients have suggested a café or tea stall, a swing for the children, displaying the rate card at the reception desk, and more seating. PSS providers are clearly pleased that their clinics have a reputation for excellence and that former clients, medical providers, chemists, ${ }^{3}$ and government health care workers all recommend their services. O ne provider proudly noted that "the only women who don't come here are women who don't know about us."

\footnotetext{
${ }^{3}$ The English term in India for pharmacists.
}

\section{Maintaining Quality: Behind the Scenes}

The commitment to providing safe, efficient, and humane abortion services has been a hallmark of the success of PSS. Much thought and effort go in to improving quality of care. Some aspects of quality have been institutionalized evenly across the organization. For example, service protocols are standardized, and compliance is assessed through the use of strict procedural guidelines and checklists. At the time of employment, every clinic employee is trained in clinic procedures. Refresher programs are conducted to meet the changing needs of the clientele. A trained outside observer periodically monitors activities at the clinics and in community projects. The purpose of these evaluations is not to critique the staff, but rather to assist them to articulate problems in service delivery, correct shortfalls, and plug loopholes.

For some aspects of quality, however, maintaining uniform standards across such a culturally and economically diverse country is a herculean task. For example, while all clinics have two toilets, standby electric generators, and a reliable 24-hour water supply, there is tremendous diversity in the size and condition of each facility. A modern clinic in an upper-income subdivision of Delhi may be cramped but maintained in pristine condition, while a large clinic in a poor periurban neighborhood remains in need of substantial repairs and renovation. O ptimizing the available resources, therefore, requires a great deal of cooperation and patience as steady (but often frustratingly slow) improvements are made. PSS's ability to upgrade facilities is greater if it owns the building, but many of its clinics are in rented sites. Investing in physical improve- 
ments in a rented space is particularly risky because PSS has been forced to vacate sites either because of rent hikes or because landlords have demanded exorbitant payments from the organiza-

\section{Since PSS provides a wide range of reproductive health services that includes abortion, there is no social stigma attached to being an abortion provider.}

tion after the clinics have started functioning. To avoid such disruptive moves and allow more investment in site improvements, PSS is trying to purchase clinic premises wherever possible.

Another hallmark of the PSS approach has been its responsiveness to the community's demand for a broader range of related reproductive health services. Although abortion is PSS's flagship service in the clinics and remains

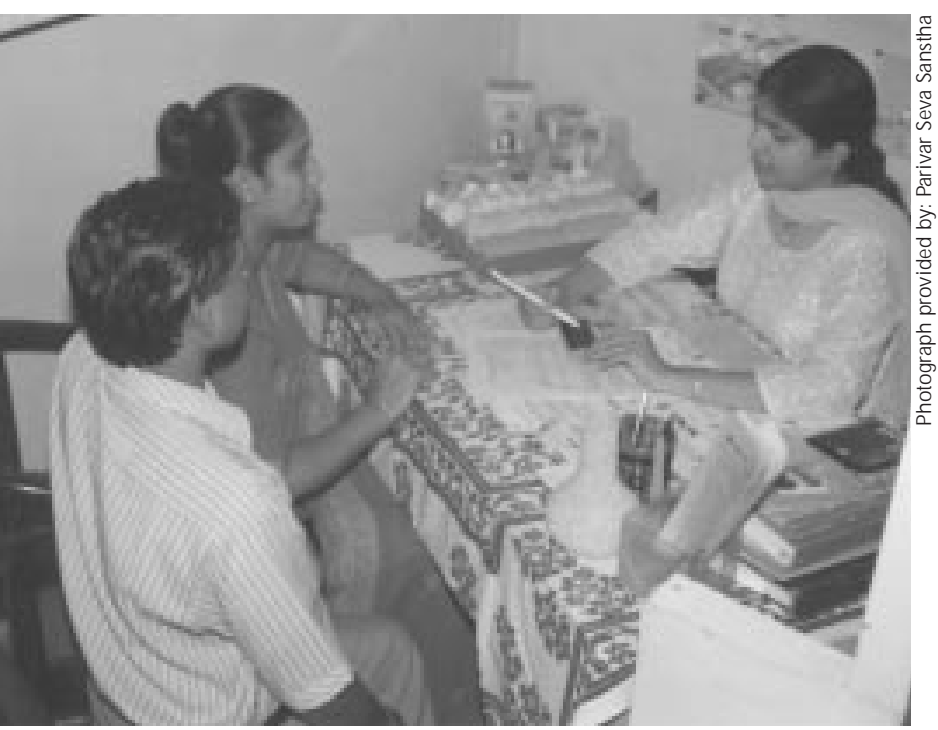

PSS has expanded from a singular focus on abortion to provide testing for STIs (including HIV), infertility checkups, and gynecological care. central to its mission, staff learned early on that their abortion clients generally had inadequate knowledge of and access to contraceptive methods, suffered from infection, or needed counseling. Hence, PSS expanded from a singular focus on abortion provision to a more comprehensive reproductive health agenda. As one staff member at PSS explained, "In order to provide abortion services, we found it was necessary to fix some problems as well."

PSS began providing family planning counseling, as well as IUDs, pills, condoms, Depo-Provera, and sterilization. The clinics also began to offer gynecological consultations, infertility checkups, and diagnosis and treatment for reproductive tract infections and STIS, including HIV. Some of the clinics also have laboratory facilities; where no lab facilities exist, the flow chart of syndromic management based on national AIDS control guidelines is followed. PSS also opened two clinics for men, as pilots, again offering a broad range of reproductive health services, including vasectomy and condoms, STI and HIV testing, and infertility testing.

$O$ ver the years, communities have expressed a demand for an even wider array of reproductive health services. In response to these concerns, PSS developed an integrated program comprised of immunization, pediatric services, and antenatal and postnatal care. These programs were specifically designed to make pregnancies healthier and deliveries safer as well as to decrease infant mortality. PSS also increased its immunization program and strengthened links with the government maternal and child health services.

To promote education, engage the community in its projects, foster public trust in the institution, and generate new clients, PSS developed projects involving volunteers. 0 pinion leaders helped 


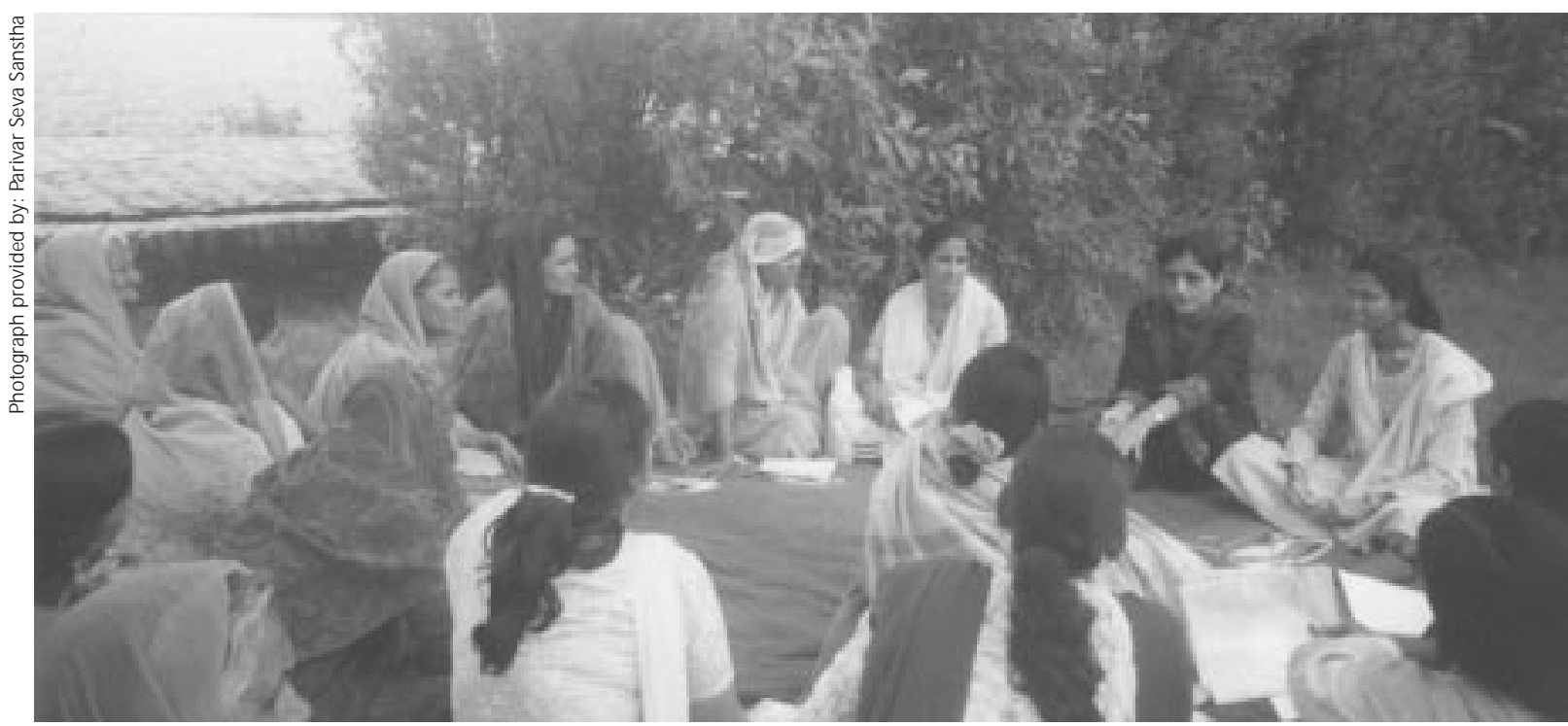

PSS now operates a vast program relying on community-based volunteers, who educate other women about reproductive health.

select local women to act as PSS education and community-based distribution (CBD) volunteers. These women are then trained in various aspects of reproductive health and disseminate this information to other women. O ver time, these programs have grown into huge endeavors of their own. ${ }^{4}$

Like many other NGOs, PSS faces difficulties in recruiting and retaining staff, particularly in rural or remote areas. All of the clinics strive to employ a minimum of one counselor, two doctors, two nursing staff, one clinic attendant, one clinic aide, and two field staff. Most doctors and other staff members stated that they choose to work at PSS because of its professional environment. As one clinic counselor said:

\footnotetext{
${ }^{4}$ In Sitapur, in the state of U ttar Pradesh, the community-based distribution system reached the doorsteps of 300,000 people before the project came to an end. In another program in the towns of Bhubaneswar and Balasor in O rissa state, CBD workers are currently reaching 200,000 urban slum dwellers.
}

I have been with Marie Stopes for 16 years. It has been a learning experience for me: helping people make contraceptive choices, and handling clinic accounts and promotional activities. All this has helped me grow personally as well as professionally.

Since PSS provides a wide range of reproductive health services that includes abortion, there is no social stigma attached to being an abortion provider. However, turnover is exacerbated by other factors. Because PSS is a nonprofit social service enterprise, salary levels are not comparable to what staff could earn in other sectors. Further, most of the clinic staff, especially doctors, are women. Some leave when their husbands are transferred to new places. 0 thers, who work at the clinics for a few years when their children are young, later want to hone their professional skills and venture into other areas. As is common for many programs, there is also relatively high turnover of field staff. 
Many clinics cope with the resulting shortages by training staff members to work as a team and perform multiple functions. This multi-tasking offers many advantages by helping individuals grow professionally and building team spirit. It also increases productivity and teaches staff to work under pressure. Moreover, maintaining a staff that performs interchangeable jobs allows the services to operate smoothly and efficiently. To keep up staff morale and improve communication, each clinic convenes monthly meetings that provide continuing education on medical topics, including new contraceptive methods.

\section{Through its 33 clinics, PSS cares}

for more than $\mathbf{1 . 5}$ million women

and men every year. Since its

inception in 1979, approximately

802,000 abortions have been

performed. retail marketing, maintaining quality while keeping prices affordable is still a challenge. The abortion service generally helps PSS sustain itself financially, as do the social marketing, STD/RTI treatment, and Medicheck (complete reproductive checkups for women) programs available at some clinics. However, resources vary from one community to another and it takes a couple of years for a new clinic to become self-sufficient. Sites in low-income areas and new sites are subsidized by PSS. To foster realistic goals for achieving quality, each PSS clinic devises its own plan for incremental improvements in care.

\section{Parivar Seva Sanstha Today}

O ver the past 20 years, PSS has grown steadily. Today PSS boasts a network of 33 clinics, two mobile units, and numerous projects and programs located in 18 of India's 28 states, including the impoverished states of Rajasthan, Uttar Pradesh, Madhya Pradesh, Bihar, and O rissa. Through these clinics, PSS cares for more than 1.5 million women and men every year. Since its inception in 1979, approximately 802,000 abortions have been performed in the Marie Stopes clinics, of which 72,000 were performed in the year 2000. PSS owes this growth in part to concerted efforts to expand access, especially to marginalized groups. For example, PSS deliberately attempts to locate its clinics in the heart of communities with high population densities and low economic resources. When this strategy is impractical or not feasible, PSS brings services directly to clients' doorsteps through mobile clinics, which offer a broad 


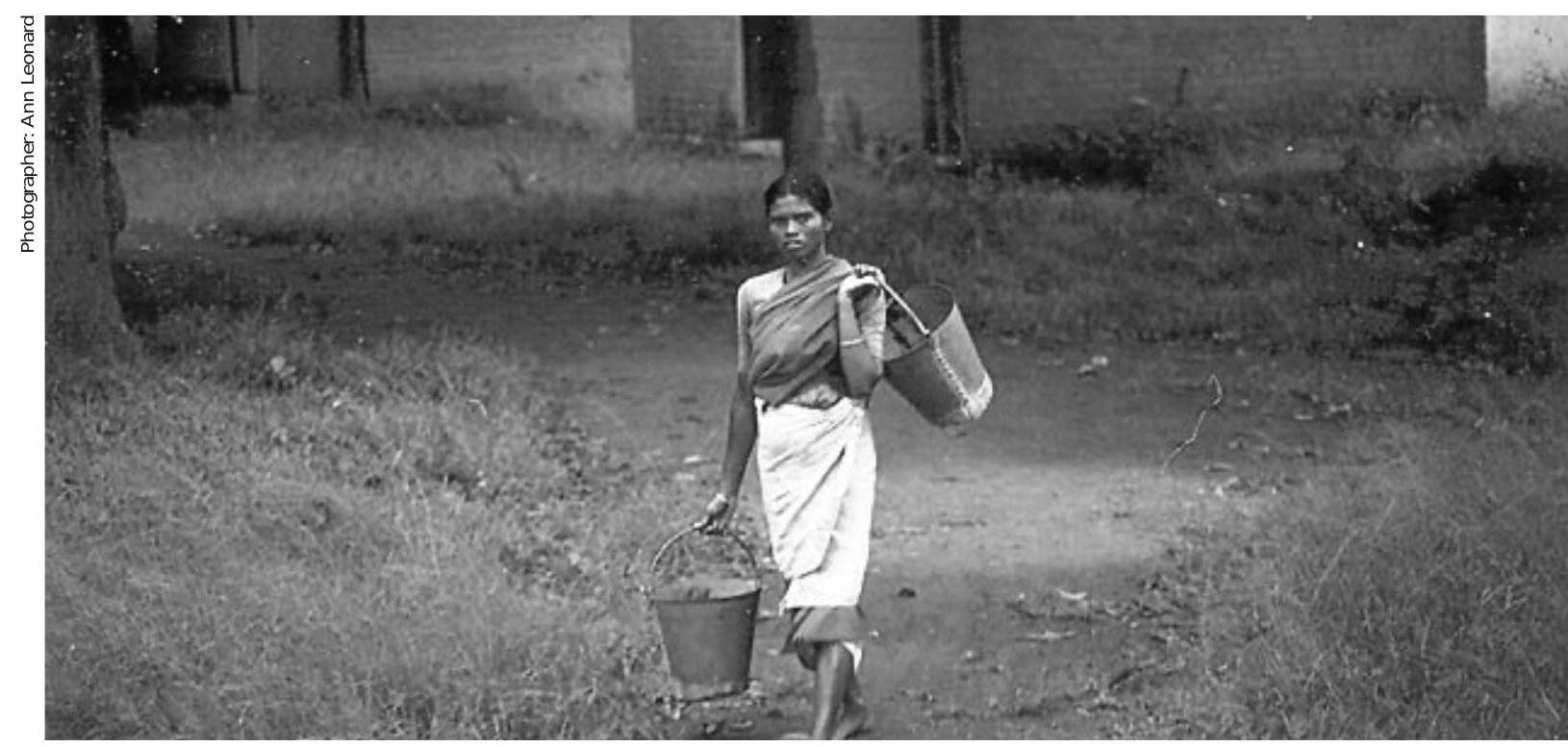

The primary mission of PSS - to enhance people's quality of life through improving their reproductive health- has not changed. The right to terminate pregnancy with safety, dignity, and personal support is part of that mission.

range of reproductive health services (excluding abortion) and through a network of field workers who spread the word about the services. PSS has also made impressive strides to reach young people and men. In 1987, it launched an ambitious Family Life Education Project, which worked through community institutions to provide young people information about health, reproduction, sexuality, contraception, parenting, and interpersonal relationships. This project has now extended its audience through a distance-learning program, a correspondence course that awards candidates a certificate on satisfactory completion of the course. To reach men, PSS started male-only clinics in the states of Tamil Nadu and $O$ rissa that offer an integrated package of services to men with a special emphasis on family planning and men's reproductive health.

Along with its clinical and programmatic innovations, the cornerstone of PSS's success remains its commitment to quality and to a client orientation. The primary mission-to improve the quality of life of people through improving their reproductive health-has not changed. N or has the belief that women seeking to terminate pregnancy have the right to do so with safety, dignity, and personal support.

\section{Reference}

Chhabra, Rami and S.C. Nuna. 1993. Abortion in India: An Overview. New D elhi, India: Veerendra Printers. 


\section{Resumen en Español}

D ado que el acceso al aborto legal y seguro se encuentra severamente limitado en muchas partes del mundo, se le ha prestado muy poca atención al tema de la calidad de la atención relacionada al aborto. Esta edición de Quality/Calidad/Qualité examina dos programas que operan en contextos legal es que permiten servicios seguros, pero que también han hecho un gran esfuerzo por analizar y practicar la calidad en la atención relacionada al aborto.

En el Hospital Broussais Clinique d'O rthogénie en Francia, un pequeño y dedicado equipo atiende a una diversa población urbana. Además de practicar procedimientos seguros, el equipo busca potenciar a sus clientes, para que ellas puedan decidir qué servicios necesitan, qué tecnología quieren utilizar, y qué calidad de salud y de vida desean tener. Por lo dicho el personal pone en manos de las mujeres clientes todo el poder de elección y la responsabilidad posibles. Según la etapa gestacional en la que se encuentran, las mujeres que acuden a la clínica pueden elegir un aborto quirúrgico o médico, consistiendo el último en el uso combinado de mifepristona (RU 486) y misoprostol. La clínica Broussais desempeñó un papel de pionero al introducir el aborto médico en 1983, y aunque este protocolo generalmente requiere tres visitas a lo largo de dos semanas, en la actualidad es el que más solicitan sus clientes.

Con el propósito de fomentar la capacidad de reflexión y decisión informada de sus clientes, el programa Broussais le da muchísima importancia al proceso de orientación, el cual suele estar enfocado en las inquietudes, experiencias, y futuras intenciones reproductivas de la mujer. Muchos de los miembros del personal creen que la buena orientación proporciona oportunidades para el crecimiento personal e incluso "ayuda a mejorar las tasas de éxito de los abortos médicos (que hoy rondan por el 99 por ciento) dado que a las mujeres que están más tranquilas les resulta más fácil (expulsar los productos de la concepción)". Nuevos miembros del personal de orientación reciben unas 400 horas de capacitación especializada, una inversión notable, incluso en un entorno donde se dispone de recursos suficientes para garantizar la salud pública.

Resulta muy distinta la situación de Parivar Seva Sanstha (PSS), una entidad afiliada a M arie Stopes International que opera 33 clínicas a lo largo de la India. Aunque el aborto es legal en la India, el acceso a servicios seguros y de bajo precio es sumamente limitado. La PSS se destaca por proveer servicios que reúnen esos dos requisitos, y que además tratan de una manera sensible y respetuosa a las mujeres. Se le da mucha importancia a la utilización de espacios que protegen la intimidad de la mujer durante las sesiones de orientación, y al mantenimiento de una confidencialidad absoluta. También se trata de brindar una mejor calidad de apoyo durante el aborto en sí, al cual la mayoría de las mujeres se someten sin anestesia. El 70 por ciento de las clientes para aborto eligen algún tipo de anticoncepción, y la esterilización simultánea es una de las opciones.

La PSS también ha sido innovadora en cuanto a métodos para el aborto. Fue una de las primeras organizaciones en India que utilizó equipos manuales para la aspiración al vacío, y ahora está por participar en pruebas clínicas de mifepristona. La PSS mantiene sus parámetros de calidad a través de protocolos, capacitación y subsidios parciales a las clínicas ubicadas en sectores más carenciados.

La PSS ha crecido según las necesidades de la comunidad, convirtiéndose poco a poco en un proveedor de servicios integrales de salud reproductiva. También ha creado un programa para jóvenes, un programa de mercadeo social para incrementar el acceso y fortalecer la cadena de abastecimiento, y otros programas basados en la comunidad.

Cada año unas 78.000 niñas y mujeres mueren innecesariamente en todo el mundo a causa de abortos mal practicados, y decenas de miles de otras mujeres sufren temor y trauma por la misma causa. Las lecciones de estos dos programas-que enfatizan seguridad, opciones, y compasión-nos hacen acordar que ya no se puede justificar el sufrimiento de cualquier niña o mujer que decide abortar. 


\section{Résumé en Français}

L'accès à l'avortement légal et sans risques étant soumis à de sévères contraintes dans de nombreux pays du monde, la question de la qualité des soins en cas d'avortement n'a pas beaucoup retenu l'attention du public. Ce numéro de $Q$ uality/Calidad/ Q ualité met en valeur deux programmes gérés dans des contextes légaux permettant l'accès à des services sans risques, mais aussi dont les responsables s'efforcent de concevoir et d'offrir des soins de qualité en cas d'avortement.

A la Clinique d'O rthogénie de l'hôpital Broussais en France, une petite équipe dévouée dessert une population urbaine hétérogène. L'équipe a pour but non seulement de pratiquer des interventions sans risques, mais aussi d'habiliter ses clientes à décider des services dont elles ont besoin, des techniques qu'elles veulent utiliser, ainsi que de la qualité de leur santé et de leur vie en général. Aussi, le personnel laisse-t-il autant que possible les clientes faire des choix et assumer des responsabilités. Suivant l'état d'avancement de la grossesse, les clientes peuvent choisir soit un acte chirurgical soit l'avortement médical, qui consiste en I'association de mifépristone (RU 486) et de misoprostol. La clinique de Broussais a lancé l'usage de l'avortement médical en 1983 et, bien qu'en général le protocole nécessite trois visites pendant une période de deux semaines, l'avortement médical est actuellement la méthode la plus utilisée parmi ses clientes.

Pour développer l'aptitude des clientes à réfléchir et à prendre des décisions éclairées, le programme de l'hôpital Broussais accorde la priorité absolue au processus de conseil, qui est souvent axé sur les préoccupations des clientes, leurs expériences, et leurs intentions futures en matière de procréation. Plusieurs membres du personnel considèrent que des conseils adéquats favorisent le développement individuel et permettent même «d'améliorer le taux de réussite de l'avortement médical (maintenant de 99 pourcent) parce que les femmes plus détendues réussissent plus facilement (à évacuer les produits de la conception).» Les nouveaux conseillers reçoivent 400 heures de formation spécialisée, ce qui représente un investissement remarquable même dans un cadre disposant de ressources adéquates pour les soins de santé publique.

Travaillant dans un cadre très différent, le Parivar Seva Sanstha (PSS), qui gère 33 cliniques dans I'ensemble de I'Inde, est affilié à M arie Stopes International. Q uoique l'avortement soit légal en Inde, l'accès à des services sûrs et abordables fait grandement défaut. Le PSS est fier non seulement d'offrir des soins sûrs et abordables, mais aussi de le faire dans un cadre accueillant et respectueux. U ne attention toute particulière est prêtée à l'établissement de lieux privés pour les séances de conseil (y compris un soutien supplémentaire pendant I'intervention, que la plupart des femmes supportent sans anesthésie) et au maintien d'une confidentialité absolue. Soixante-dix pour cent des clientes ayant subi un avortement optent pour la contraception; la stérilisation est également disponible.

Le PSS a aussi été un novateur en ce qui concerne les méthodes d'avortement. L'un des premiers programmes en Inde à utiliser le matériel d'aspiration manuelle intra-utérine, il est maintenant prêt à participer aux essais relatifs au mifépristone. Les normes de qualité sont maintenues grâce à des protocoles, à la formation du personnel, ainsi qu'à des subventions partielles aux cliniques situées dans les zones particulièrement pauvres en ressources.

En réponse aux besoins de la communauté, le PSS s'est développé au fil des ans afin de devenir un prestataire de services complets de santé de la reproduction. II a aussi élaboré un programme pour les jeunes, un programme de marketing social pour accroître l'accès aux services et en assurer la prestation ininterrompue, ainsi que d'autres programmes communautaires.

Chaque année, 78000 filles et femmes meurent inutilement dans le monde des suites d'un avortement pratiqué dans de mauvaises conditions de sécurité, et de nombreuses autres encore connaissent la peur ainsi qu'un traitement inhumain. Les leçons tirées de ces deux programmes qui mettent l'accent sur la sécurité, le choix, et la compassion nous rappellent qu'il n'y a pas de raison qu'un avortement se passe dans la souffrance. 


\section{A bout the Authors}

Carmen Barroso is Director of the Population Program at the John D. and Catherine T. MacArthur Foundation.

Martha Brady is a Program Associate with the Gender, Family, and Development Program of the Population Council.

Shelley Clark was formerly a Program Associate in the International Programs Division of the Population Council.

Batya Elul is a Staff Program Associate in the International Programs Division of the Population Council.

Sunanda Rabindranathan is the Communications and Research Executive at the Parivar Seva Sanstha.

Sneh Vishwanath was the Medical Advisor to Parivar Seva Sanstha.

Editor: Debbie Rogow

Editorial and

Production Coordinator: Monica Rocha

Designer: Mike Vosika

\section{Advisory Group}

Errol Alexis

Gary Barker

Judith Bruce

Françoise Girard

$\mathrm{N}$ icole $\mathrm{H}$ aberland

Joan Haffey

Judith Helzner

Katherine Kurz

Ann Leonard

Elizabeth McGrory

Suellen Miller

Isaiah N dong

Nancy Newton

John Paxman

Saumya RamaRao

Julie Reich

Jill Sheffield

Cynthia Steele

Gilberte Vansintejan

Beverly Winikoff

Margot Zimmerman

We invite your comments and ideas for projects that might be included in future editions of $Q$ uality/Calidad/Q ualité. If you would like to be included on our mailing list, please send an e-mail to: qcq@popcouncil.org. Most past editions are available online at: www.popcouncil.org/publications. The following are also available in print; single or multiple copies may be ordered by e-mail:

Celebrating Mother and Child on the Fortieth Day: The Sfax Tunisia Postpartum Program (English only), no. 1, 1989.

Man/Hombre/Homme: M eeting Male Reproductive Health Care Needs in Latin America (English, Spanish), no. 2, 1990.

Gente Joven/Young People: A Dialogue on Sexuality with Adolescents in M exico (English, Spanish), no. 5, 1993.

The Coletivo: A Feminist Sexuality and Health Collective in Brazil (English, Portuguese), no. 6, 1995.

Doing More with Less: The Marie Stopes Clinics of Sierra Leone (English only), no. 7, 1995.
Introducing Sexuality within Family Planning: Three Positive Experiences from Latin America and the Caribbean (English, Spanish), no. 8, 1997.

U sing COPE to Improve Q uality of Care: The Experience of the Family Planning Association of Kenya (English, Spanish), no. 9, 1998.

Alone You Are Nobody, Together We Float: The Manuela Ramos Movement (English, Spanish), no. 10, 2000. 